\title{
PERLINDUNGAN HUKUM TERHADAP ANAK PELAKU PERKOSAAN BERDASARKAN HUKUM POSITIF INDONESIA
}

\author{
Oleh: \\ Bambang Heri Supriyanto \\ Fakultas Hukum Universitas Azzahra, Jakarta \\ Email: cri1_one@yahoo.com
}

\begin{abstract}
ABSTRAK
Perlindungan hukum terhadap anak yang melakukan kejahatan perkosaan adalah merupakan keharusan dimana anak merupakan aset keberhasilan peradaban bangsa dan negara dimasa depan, karenanya dalam menyikapi tindak kejahatan yang dilakukan oleh anak, dalam pelaksanaannya jangan disamakan dengan orang dewasa. Seyogyanya permasalahan anak menjadi perhatian semua bagian masyarakat utamanya pemerintah baik dengan kebijakan maupun dalam pelaksanaan peraturan perundang-undangan yang telah dibuat oleh Negara selaku penyelenggara amanah rakyat. Anak yang melakukan kejahatan bukan mutlak kesalahan dirinya namun dikarenakan faktor-faktor pendorong baik dari dalam maupun dari luar dirinya. Maka penulis mencoba menjabarkan permasalahan diantaranya; berkenaan dengan perlindungan hukum terhadap anak sebagai pelaku perkosaan, kemudian penerapan hukum terhadap anak sebagai pelaku perkosaan berdasarkan perundang-undangan yang berkenaan dengan anak selanjutnya pandangan hukum islam mengenai perlindungan anak pelaku perkosaan. Disimpulkan faktor-faktor yang melatar belakangi terjadinya kejahatan perkosaan, faktor internal; umur dilihat dari fisik, psikis dan sosiologis dan faktor eksternal; bacaan atau film pornografi, keluarga, kesempatan, paling dominan krisis nilainilai agama dan moral, ekonomi, dll. Anak sebagai pelaku kejahatan kesusilaan ini memerlukan dan mempunyai hak dengan dasar hukum (legal rigths) sebagai bentuk hak asasi manusia. Perlindungan hukum sebagai dasar penyembuhan fisik, kejiwaan dan memulihkan kembali hak anak yang seharusnya dimilikinya. dalam hukum Islam mempunyai aturan yang jelas, kedudukan anak dalam hukum Islam merupakan amanah yang harus dijaga orang tuanya. Kewajiban untuk mendidiknya hingga berperilaku sebagaimana yang dituntun dalam agama. Jika terjadi penyimpangan dalam tingkah laku anak, Islam dalam keadaan tertentu masih memberi kelonggaran ketidakberdosaan "raf'ul qalam" seorang anak hingga mencapai akil baligh.
\end{abstract}

Kata Kunci: Perlindungan Hukum, Anak, Perkosaan

\begin{abstract}
The Legal protection of children who commit the crime of rape is imperative that children are the assets of civilization and the country's success in the future, hence in addressing the crimes committed by children, in practice should not be confused with an adult. Problems of children should be the primary concern of all sections of society with good government policy and the implementation of the
\end{abstract}


laws that have been made by the State as the organizer of the mandate of the people. Children who commit crimes is not absolute fault itself but because of the factors driving both from within and from outside. The author tried to explain the problems are; with regard to the legal protection of children as perpetrators of rape, then the application of the law against children as perpetrators of rape based on legislation relating to child views subsequent Islamic law regarding the protection of child rape. Concluded the factors of the background of the crime of rape, internal factors; age seen from the physical, psychological and sociological and external factors; reading or pornographic movies, family, opportunity, most dominant crisis of religious values and morals, economics, etc. Children as perpetrators of this decency and has a right to require a legal basis (legal rights) as a form of human rights. Legal protection as a basis of physical healing, psychological and restore the rights of children are supposed possession. Islamic law has clear rules, the position of the child in Islamic law is a mandate that should be kept by parents. The obligation to educate him to behave as guided in religion. If there are deviations in the child's behavior, Islamic under certain circumstances still gives leeway innocence "raful qalam" of a child until it reaches puberty.

Keywords : Legal Protection, Child, Rape

\section{PENDAHULUAN}

Tidak ada yang dapat menafikan bahwa anak adalah aset bangsa. Sebagai bagian dari generasi muda, anak berperan sangat strategis, yakni sebagai pewaris (successor) bangsa, penerus cita-cita perjuangan bangsa sekaligus potensi sumber daya manusia bagi pembangunan nasional. Anak merupakan pewaris dan penentu kemajuan suatu peradaban di masa yang akan datang oleh karenanya dalam mengelola dan menyiapkan seyogyanya harus dilakukan dengan menjunjung tinggi nilai-nilai budi pekerti yang arif dan bijaksana (El Muhtaj, Majda Zuhdi Manik (Ed.), 1999, 19).

Pada akhir abad ke-19, kriminalisasi yang dilakukan oleh anak dan remaja semakin meningkat, sehingga dalam menghadapi fenomena tersebut diperlukan penanganan terhadap pelaku kriminal anak disamakan dengan pelaku kriminal orang dewasa. Hal ini merupakan suatu konsekuensi dari hukum yang ada pada saat itu belum memiliki aturan khusus yang mengatur tentang anak yang berhadapan dengan hukum atau anak pelaku tindak pidana.

Dalam perkembangan selanjutnya, di berbagai negara dilakukan pula usaha-usaha ke arah perlindungan anak termasuk dengan dibentuknya pengadilan anak (Juvenile Court) yang pertama di Minos, Amerika Serikat pada tahun 1889, 
dimana undang-undangnya didasarkan pada asas 'parents patriae', yang berarti bahwa penguasa harus bertindak apabila anak-anak membutuhkan pertolongan, atau dengan kata lain apabila anak dan pemuda melakukan kejahatan sebaiknya tidak diberi pidana melainkan harus dilindungi dan diberikan bantuan.

Justifikasi konstitusional melindungi anak sebagai urusan utama berbangsa dan bernegara, tertuang dalam Pasal 28 ayat (2) UUD 1945 secara ekplisit telah menegaskan hak-hak konstitusional anak yang berbunyi, "Setiap anak berhak atas kelangsungan hidup, tumbuh dan berkembang, dan perlindungan dari berbagai bentuk kekerasan dan diskriminasi”. Negara Republik Indonesia secara konstitusional telah eksplisit mengakui, menghormati dan melindungi hak-hak konstitusional anak, yakni:

a. hak atas kelangsungan hidup;

b. hak atas tumbuh dan berkembang, dan;

c. hak atas perlindungan dari kekerasan dan diskriminasi;

Oleh karena itu menjadi kewajiban bagi orang dewasa baik orang tua, keluarga, masyarakat maupun bangsa untuk memberikan jaminan, memelihara dan mengamankan kepentingan anak serta melindungi dari gangguan yang datang dari luar maupun dari anak itu sendiri. Yang pada kenyataannya hal tersebut masih belum diutamakan jika tidak dikatakan hanya sekedar melaksanakan prosedur formal yuridis. (Asnifriyanti, 2008, 26)

Sepanjang dunia ini tidak sepi dari anak-anak, selama itu pula masalah anak akan selalu dibicarakan. Perhatian akan perlunya perlindungan khusus bagi anak berawal dari deklarasi Jenewa tentang hak-hak anak tahun 1924 yang diakui dalam Universal Declaration of Human Right tahun 1958. Bertolak dari itu kemudian pada tanggal 20 November 1958 Majelis Umum PBB mengesahkan Declaration Of Rigths of The Child (Deklarasi Hak Anak), sementara itu masalah anak terus di bicarakan dalam kongres-kongres $\mathrm{PBB}$ mengenai The Prevention of Crime and the Treatment Of Offenders. (Kunarto, 2005, 40)

Pada kongres ke-I di Jenewa tahun 1955 dibicarakan topik Prevention of Juvenile Delinquency. Pada tahun 1959 Majelis Umum PBB kembali mengeluarkan pernyataan mengenai hak-hak yang merupakan Deklarasi International ke dua bagi hak anak. Tahun 1989, rancangan konvensi hak anak 
diselesaikan dan pada tahun itu juga naskah akhir tesebut disahkan dengan suara bulat oleh majelis umum PBB tanggal 20 November. Kovenan ini kemudian diratifikasi oleh setiap bangsa kecuali oleh Somalia dan Amerika Serikat.

Dalam pasal 16 ayat (1) Konvensi Hak Anak disebutkan bahwa tidak ada seorang pun anak yang dikenai campur tangan semena-mena atau tidak sah terhadap kehidupan pribadinnya, keluarga, rumah atau surat menyurat, atau mendapat serangan tidak sah atas harga diri dan reputasinya. Selanjutnya ayat (2) disebutkan bahwa anak berhak untuk memperoleh perlindungan hukum dari campur tangan atau serangan semacam itu. Dapat ditarik pengertian bahwa anak berhak untuk memperoleh perlindungan dari gangguan terhadap kehidupan pribadi, keluarga, rumah dan surat menyurat serta fitnah. (Nursyahbani Katjasungkana, 21, 2007)

Adapun kesejahteraan Anak itu sendiri menurut Arif Gosita adalah "hak asasi anak yang harus di usahakan bersama baik oleh keluarga maupun masyarakat dimana seorang anak itu berada dan berkembang secara fisik, mental, sosial sehingga menjadi manusia seutuhnya yang berakhlak dan berbudi pekerti yang luhur". Pelaksanaan pengadaan kesejahteraan bergantung pada partisipasi yang baik antara objek dan subjek dengan seimbang dan selaras sesuai dengan perkembangan dan pertumbuhan anak yang bertujuan, yaitu sesuai dalam kesejahteraan anak. (Arief Gosita, 2003, 58)

Ini berarti bahwa setiap anggota masyarakat dan pemerintah berkewajiban ikut serta dalam pengadaan kesejahteraan anak dalam suatu masyarakat yang merata akan membawa akibat yang baik pada keamanan dan stabilitas suatu masyarakat, yang selanjutnya akan mempengaruhi pembangunan yang sedang diusahakan dalam masyarakat tersebut. Atas dasar pertimbangan tersebut, pemerintah telah menerbitkan Undang-Undang Nomor 23 tahun 2002 tentang Perlindungan Anak. Disebutkan dalam pasal 1 butir (1) Undang-Undang Nomor 23 tahun 2002 bahwa yang dimaksud dengan Perlindungan Anak adalah: segala kegiatan untuk menjamin dan melindungi anak dan hak-haknya agar dapat hidup, tumbuh, berkembang, dan berpartisipasi secara optimal sesuai dengan harkat dan martabat kemanusiaan, serta mendapat perlindungan dari kekerasan dan diskriminasi. (UU No 23 tahun 2002) 
Oleh karena itu, anak memerlukan perlindungan dalam rangka menjamin pertumbuhan dan perkembangan fisik, mental dan sosial secara utuh, serasi dan seimbang. Pelaksanaan pembinaan dan perlindungan anak butuh dukungan, baik menyangkut kelembagaan maupun perangkat hukum yang memadai ketika perbuatan jahat telah terjadi dan dilakukan oleh anak tersebut serta berhasil ditangkap oleh pihak yang berwajib, disaat itu pula hukum diperlakukan kepada mereka dan anak sebagai pelaku kejahatan yang di hadapkan kepada hukum akibat perbuatan melanggar yang mereka lakukan.

Undang-Undang tentang Sistem Peradilan Pidana Anak Pengadilan Anak merupakan Undang-undang pengganti Undang-Undang sebelumnya yaitu Undang-Undang Pradilan anak tahun 1997, merupakan hukum formil yang dipergunakan dalam memberikan keadilan dan kepastian hukum bagi anak yang melakukan kejahatan. Menurut Undang-Undang Sistem Peradilan Anak sebagai hukum formil yang dikategorikan anak adalah Pasal 1 angka 2 dan 3 menyatakan, Anak yang Berhadapan dengan Hukum adalah anak yang berkonflik dengan hukum, anak yang menjadi korban tindak pidana, dan anak yang menjadi saksi tindak pidana. Selanjutnya angka 3 berbunyi Anak yang Berkonflik dengan Hukum, yang selanjutnya disebut Anak adalah anak yang telah berumur 12 (dua belas) tahun, tetapi belum berumur 18 (delapan belas) tahun yang diduga melakukan tindak pidana.

Dalam menyelesaikan perkara anak, hakim wajib mempertimbangkan laporan hasil penelitian kepada masyarakat mengenai data pribadi maupun keluarga dari anak yang bersangkutan. Putusan Hakim mempengaruhi kehidupan selanjutnya dari anak yang bersangkutan, oleh sebab itu hakim harus yakin benar bahwa putusan yang diambil akan dapat menjadi salah satu dasar yang kuat untuk mengembalikan dan mengantar anak menuju masa depan yang baik untuk mengembangkan dirinya sebagai anak yang bertanggung jawab bagi dirinya, keluarga, masyarakat, bangsa dan negara.

Berdasarkan uraian tersebut diatas, maka penulis dapatlah dikemukakan beberapa pokok permasalahan sebagai berikut;

a. Bagaimana perlindungan hukum terhadap anak sebagai pelaku perkosaan yang terdapat dalam perundang-undangan di Indonesia 
berkenaan dengan anak?

b. Bagaimana penerapan hukum terhadap anak sebagai pelaku perkosaan berdasarkan perundang-undangan tentang peradilan anak?

c. Bagaimana pandangan hukum islam mengenai perlindungan anak sebagai pelaku perkosaan?

\section{PEMBAHASAN}

\section{A. PENGERTIAN, MODUS OPERANDI FAKTOR KEJAHATAN PERKOSAAN}

\section{Pengertian Arti Defenisi Kejahatan Perkosaan}

Perkosaan termasuk dalam kejahatan, kekerasan, kekerasan seksual dan juga merupakan hak asasi perempuan yang diinjak-injak. Perlu diketahui misalnya dalam perpektif masyarakat pada lazimnya bahwa kejahatan seksual itu bermacam-macam, seperti perzinahan, homoseksual, samen leven (kumpul kebo), lesbian, protitusi (pelacuran), pencabulan, perkosaan promiskuitas (hubungan seksual yang dilakukan di luar ikatan perkawinan dengan cara berganti-ganti pasangan). (A Wahid dan M. Irfan, 2001, 25)

Pada dasarnya perkosaan adalah bentuk kekerasan primitif yang kita semua tahu terdapat pada masyarakat manapun. Gejala sosial perkosaan merupakan salah satu tantangan yang harus dipikirkan secara serius. Sepintas kasus perkosaan tidak lebih istimewa dari kasus kekerasan lainnya, atau kalaupun jadi istimewa dari kasus kekerasan lainnya, biasanya dengan perkosaan diikuti dengan pembunuhan. Ini mungkin menyangkut cara pandang orang tentang perkosaan.

\section{Macam, Karakteristik dan Modus Operandi Perkosaan \\ a. Macam Perkosaan}

Saat ini istilah "perkosaan" cukup sering digunakan untuk suatu tindakantindakan atau perbuatan-perbuatan tertentu yang modusnya merugikan orang dan melanggar hak-hak asasi manusia, seperti "perkosaan" hak-hak sipil, "Perkosaan" ekologis (lingkungan hidup), "perkosaan" terhadap harkat kemanusiaan dan lainnya. Sedangkan memperkosa berarti menundukkan dengan kekerasan, 
menggagahi, melanggar dengan kekerasan. Tindakan ini dianggap melanggar hukum yang berlaku.

Menurut Kamus Besar Indonesia itu menunjukkan bahwa unsur utama yang melekat pada tindakan perkosaan adalah perilaku kekerasan yang terkait dengan hubungan seksual, yang dilakukan dengan jalan melanggar hukum. Artinya tidak selalu kekerasan yang terkait dengan hubungan seksual dapat dikategorikan sebagai perkosaan.

Perkosaan adalah suatu usaha melampiaskan nafsu seksual oleh seorang lelaki terhadap seorang perempuan dengan menurut moral dan/atau hukum yang berlaku melanggar. Dalam pengertian seperti ini, yang disebut perkosaan, di satu pihak dapat dilihat sebagai suatu perbuatan (ialah perbuatan seseorang yang secara paksa hendak melampiaskan nafsu seksualnya), dan di lain pihak dapatlah dilihat pula sebagai suatu peristiwa (ialah pelanggaran norma-norma dan dengan demikian juga tertib sosial).

Menurut Suagandhi, mengenai perkosaan adalah "seorang pria yang memaksa pada seorang wanita bukan istrinya untuk melakukan persetubuhan dengannya dengan ancaman kekerasan, yang mana diharuskan kemaluan pria telah masuk ke dalam kemaluan seorang wanita yang kemudian mengerluarkan air mani. Adapun unsur-unsur kelengkapanya tentang perkosaan adalah:

a. Pemaksaan bersetubuh oleh laki-laki kepada wanita yang bukan menjadi istrinya

b. Pemaksaan bersetubuh itu diikuti dengan tindak atau ancaman kekerasan

c. Kemaluan pria harus masuk pada lubang kemaluan wanita, dan

d. Mengeluarkan air mani.

Mengenai macam-macam jenis perkosaan dapat diklasifiksikan sebagai berikut di bawah ini:

1. Sadistic Rape ialah perkosaan sadistis, artinya, pada tipe ini seksualitas dan agresif berpadu dalam bentuk yang merusak. Pelaku perkosaan telah nampak menikmati kesenangan erotik bukan melalui hubungan seksnya, melainkan melalui serangan yang mengerikan atas alat kelamin dan tubuh korban. 
2. Anger Rape ialah yakni penganiayaan seksual yang bercirikan seksualitas menjadi sarana untuk menyatakan dan melampiaskan perasaan geram dan marah yang tertahan. Tubuh korban seakan-akan merupakan objek terhadap siapa pelaku yang memperoyeksikan pemecahan atas prustasiprustasi, kelemahan, kesulitan dan kekecewaan hidupnya.

3. Dononation Rape ialah yakni suatu perkosaan yang terjadi ketika pelaku mencoba untuk gigih atas kekuasaan dan superioritas terhadap korban. Tujuannya adalah penaklukan seksual, pelaku menyakiti korban, namun tetap memiliki keinginan berhubungan seksual.

4. Seduktive Rape ialah perkosaan yang terjadi pada situasi-situasi yang merangsang, yang tercipta oleh kedua belah pihak. Pada mulanya korban memutuskan bahwa keintiman personal harus dibatasi tidak sampai sejauh kesenggaman. Pelaku pada umumnya mempunyai keyakinan membutuhkan paksaan, oleh karena tanpa itu tak mempunyai rasa bersalah yang menyangkut seks.

5. Victim Precipitatied Rape ialah yakni perkosaan yang terjadi (berlangsung) dengan menempatkan korban sebagai pencetusnya.

6. Exploition Rape ialah perkosaan yang menunjukkan bahwa pada setiap kesempatan melakukan hubungan seksual yang diperoleh oleh laki-laki dengan mengambil keuntungan yang berlawanan dengan posisi wanita yang bergantung padanya secara ekonomis dan sosial.

\section{b. Karakteristik Perkosaan}

Adapun karakteristik utama (khusus) tindak pidana perkosaan yaitu ekspresi seksual agresivitas (sexual expression ofaggression). Artinya, perwujudan keinginan seks yang dilakukan secara agresif, bersifat menyerang atau memaksa lawan jenis (pihak) lain yang dapat dan dianggap mampu memenuhi kepentingan nafsunya. Karakteristik umum tindak pidana perkosaan adalah :

1. Agresivitas, merupakan sifat yang melekat pada setiap tindak pidana perkosaan.

2. Motivasi kekerasan lebih menonjol dibandingkan dengan motivasi 
seksual semata-mata.

3. Secara psikologis, tindak pidana perkosaan lebih banyak mengandung masalah kontrol dan kebencian dibandingkan dengan hawa nafsu.

4. Tindak pidana perkosaan dapat dibedakan ke dalam tiga bentuk, yaitu ;

a. anger rape,

b. power rape dan sadistis rape,

c. direduksi dari anger and violation, control and domination, erotis.

5. Ciri pelaku perkosaan : mispersepsi pelaku atas korban, mengalami pengalaman buruk khususnya dalam hubungan personal (cinta terasing dalam pergaulan sosial, rendah diri, ada ketidakseimbangan emosional.

6. Korban perkosaan adalah partisipatif. Menurut Meier dan Miethe, 4 19\% tindak pidana perkosaan terjadi karena kelalaian (partisipasi) korban.

7. Tindak pidana perkosaan secara yuridis sulit dibuktikan. Di antara karakteristik perkosaan itu, ciri kekerasan dan sulitnya dilakukan pembuktian tampaknya perlu mendapatkan perhatian utama.

Kekerasan yang menimpa korban bukan hanya berdampak merugikan ketahanan fisiknya namun juga ketahanan psikologisnya. Kondisi buruk yang membuat korban tidak berdaya ini dapat berdampak buruk lebih lanjut pada persoalan penegakan hukumnya.

\section{c. Modus Operandi Perkosaan}

Setiap kejahatan yang terjadi atau dilakukan secara individual maupun kelompok, terutama yang direncanakan, tentulah didahului oleh suatu modus operandi. Modus operandi inilah yang menjadi fokus pembahasan dari kasus perkosaan yang terjadi. Modus operandi kejahatan perkosaan ini biasanya menunjukkan cara-cara pemaksaan kehendak, pengancaman dan kekerasan. Di samping perkosaan itu sendiri termasuk kejahatan yang berkarakter kekerasan, modus operandi yang dilaksanakan juga mengandung kekerasan. Suatu perbuatan dikatakan perkosaan apabila salah satunya terdapat unsur kekerasan atau ancaman kekerasan di dalamnya. Suatu cara atau upaya demikian biasanya dapat pula disebut sebagai modus operandi. Modus Operandi adalah teknik atau cara-cara 
beroperasi yang dipakai oleh pelaku. (R. Soesilo, 1980, 19)

Tiap-tiap pelaku kejahatan dalam melakukan kejahatannya menggunakan cara yang beraneka ragam, khusus dan antara cara yang satu dengan pelaku yang lain biasanya tidak sama. Modus operandi suatu perbuatan dapat dilakukan dengan satu perbuatan atau lebih, bahkan merupakan kombinasi dari beberapa perbuatan.

Faktor-faktor yang mempengaruhi modus operandi dilatarbelakangi oleh pelaksanaan kehendak dan beberapa faktor lain. Semua kejahatan dilatarbelakangi oleh 2 faktor, yaitu :

1. kesempatan (opportunity) berupa kebetulan atau diciptakan dan

2. kebutuhan (need) yang sebenarnya atau diimpikan.

Kedua faktor ini ditingkatkan menjadi aksi atau paksaan yang didasarkan pada keinginan (desire) apakah normal atau abnormal. Korban perkosaan merupakan praktek kekerasan yang dilakukan oleh pelaku. Pihak pemerkosa telah menggunakan ancaman dan kekerasan (paksaan) untuk menundukkan korban. Korban dibuat takut sehingga tidak berani melawan, atau dibuat tidak berdaya sehingga mau mengikuti kehendak pelaku.

Derita korban bisa lebih parah dibandingkan kalau perkosaan yang menjadi tujuannya. Sebab, bukan tidak mungkin kekecewaan yang tidak tercapai yang dilakukan oleh pelaku dapat membuatnya berlaku lebih nekat dan sadis dengan membunuh korbannya. Oleh karena itu, kalau dikonklusikan, modus operandi perkosaan setidak-tidaknya sebagai berikut:

1. diancam dan dipaksa,

2. dirayu,

3. dibunuh,

4. diberi obat bius,

5. diberi obat perangsang,

6. dibohongi atau diperdaya dan lainnya.

Modus operandi perkosaan seperti itu sangat mungkin di kemudian hari dapat berkembang dan dapat bermodus operandi lainnya. Karena, modus operandi kejahatan itu, selain terkait dengan posisi korban atau objek yang menjadi sasarannya, juga terkait dengan perkembangan sosial, budaya, ekonomi dan 
politik yang terjadi dan bergolak di tengah masyarakat. Hal ini sama dengan suatu adagium yang menyebutkan "semakin maju suatu masyarakat, maka semakin maju pula perkembangan kejahatannya". Artinya, ada saja jenis dan modus operandi baru di dunia kejahatan, karena beradaptasi dengan perkembangan yang ada.

\section{Faktor-Faktor Penyebab Kejahatan}

Secara teoritis, banyak faktor penyebab terjadi aksi kejahatan, termasuk kejahatan perkosaan. Namun tentu dimensi yang paling dominan adalah terjadi krisis nilai-nilai agama dan moral, yang secara lahiriah dan batiniah merupakan batasan bagi seorang manusia untuk bertindak dan bersikap. Bila manusia tidak lagi mematuhi nilai-nilai agama tersebut maka yang bersangkutan bertindak seperti binatang, bahkan mungkin lebih buruk. Buktinya, seorang bapak tega memperkosa anak kandungnya sendiri, atau seorang pemuda memperkosa dan membunuh anak berumur lima tahun.

Ditengah kondisi ekonomi dan budaya seperti ini, memang sangat besar peluang orang untuk melupakan nilai-nilai agama dan moral, "Budaya" minum alkohol, narkoba, dan judi, menjadi peluang utama terjadinya tindak kejahatan, karena yang demikian itu menghilangkan pikiran sehat seseorang. Sehingga apa yang dilakukannya lebih banyak dikendalikan nafsu, bukan akal sehat. Kondisi tersebut semakin parah, bila memang dalam diri orang tersebut jauh dari nilainilai agama.

Di suatu daerah, biasanya peran tokoh masyarakat dan tokoh agama sangat penting dalam mempengaruhi tindakan masyarakat, termasuk menyadarkan pada orang tua pentingnya menanamkan sejak dini nilai-nilai agama dan moral kepada anak-anak. Disamping ini penyebab terjadinya kriminalitas, pencurian dan perampokan dari aspek sosial dan psikologis adalah faktor endogen dan eksogen.

Faktor endogen adalah dorongan yang terjadi dari dirinya sendiri, seperti suatu kebenaran relatif itu bisa menciptakan suatu sikap mempertahankan pendapatnya, diri, atau egosentris dan fanatis yang berlebihan. Jika seseorang tidak bijaksana dalam menanggapi masalah yang barangkali menyudutkan dirinya, maka kriminalitas itu bisa saja terjadi sebagai pelampiasan untuk menunjukkan bahwa dialah yang benar. Sementara faktor eksogen adalah faktor yang tercipta 
dari luar dirinya, faktor inilah yang bisa dikatakan cukup kompleks dan bervariasi. Kesenjangan sosial, kesenjangan ekonomi, ketidakadilan, dsb. Semua itu merupakan contoh penyebab terjadinya tindak kriminal yang berasal dari luar dirinya. (Bimo Walgito, 1997, 45)

Pengaruh sosial dari luar dirinya misalnya, ajakan teman, tekanan atau ancaman pihak lain, minum-minuman keras dan obat-obatan terlarang yang membuat ia tidak sadar. Pengaruh ekonomi misalnya karena keadaan yang serba kekurangan dalam kebutuhan hidup, seperti halnya kemiskinan memaksa seseorang untuk berbuat jahat. (Bimo Walgito, 1996, 57)

Dampak dari kriminalitas itu tidak saja merugikan individu itu sendiri dan orang lain melainkan akan melahirkan atas kejahatan dan antitesa kejahatan yang baru serta berkelanjutan. Secara konsepsual usaha pembinaan terhadap pelaku kejahatan adalah dengan memasukkan unsur-unsur yang terkait dengan mekanisme peradilan pidana dan partisipasi masyarakat antara lain: (P. Hardodo Hadi, 1999, 48).

1. Peningkatan dan pemantapan aparat penegak hukum yaitu meliputi pemantapan organisasi, personal, sarana dan prasarana, untuk dapat mempercepat penyelesaian perkara-perkara pidana.

2. Perundang-undangan berfungsi untuk menganalisis dan menekan kejahatan dengan mempertimbangkan masa depan.

3. Mekanisme peradilan yang efektif dan efisien (memenuhi sifat-sifat: cepat, tepat, murah, dan sederhana).

4. Koordinasi antara aparatur penegak hukum dengan aparatur pemerintah lainnya yang saling berhubungan atau saling mengisi untuk meningkatkan daya guna penanggulangan kriminalitas.

5. Partisipasi masyarakat untuk membantu kelancaran pelaksanaan penanggulangan kriminalitas.

Disamping upaya-upaya tersebut di atas, yang terpenting adalah upaya yang bersifat preventif atau pencegahan, yaitu dengan jalan menyadarkan atau menekan terhadap hal-hal yang dapat menimbulkan kejahatan. Disinilah peran moral dan agama untuk menuntun manusia kepada jalan yang benar. (M. Quraish Shihab 1997, 164) 
Salah satu contoh kecenderungan manusia untuk melakukan pencurian dan perampokan di beberapa tempat, apabila secara kriminologis tak bisa dicari faktor penyebab tunggal kejahatan, banyak faktor penyebab yang berkaitan, ada faktor penegakan hukum yang lemah, kesadaran hukum yang rendah, tekanan ekonomi, membudayakan korupsi, kolusi, nepotisme. Juga faktor ketimpangan sosial dan kesenjangan ekonomi. Keluasan dimensi yang dimaksud sangat bergantung pada titik pandang yang hendak dipergunakan dalam melakukan analisis teoritis terhadap subjek pembahasan. Terdapat tiga titik pandang dalam melakukan analisis terhadap masalah kejahatan, yaitu: (Atmasasmita, Romli, 2005, 71-72)

1. Titik pandang secara makro atau macro theories adalah teori-teori yang menjelaskan kejahatan dipandang dari segi structural social dan dampaknya. Teori-teori ini menitik beratkan rates of crime atau epidemiologi kejahatan dari pada atas pelaku kejahatan.

2. Titik pandang secara micro theories adalah teori-teori yang menjelaskan mengapa seseorang atau kelompok orang dalam masyarakat melakukan kejahatan atau mengapa di dalam masyarakat terdapat orang-orang yang melakukan kejahatan dan terdapat pula sekelompok orang atau orangorang tertentu yang tidak melakukan kejahatan. Teori ini menitikberatkan pada pendekatan psikologi atau sosiologis atau biologis.

3. Titik pandang secara bridging theories adalah teori-teori yang tidak atau sulit untuk dikategorikan ke dalam, baik macro theories maupun micro theries. Teori-teori yang termasuk ke dalam kategori ini menjelaskan struktur sosial dan juga menjelaskan bagaimana seseorang atau sekelompok orang menjadi penjahat.

\section{B. FAKTOR-FAKTOR YANG MENDORONG TERJADINYA PERKOSAAN.}

Setelah dijelaskan mengenai realita kejahatan perkosaan yang terjadi, selanjutnya diuraikan mengenai faktor-faktor yang melatarbelakangi terjadinya kejahatan perkosaan, Faktor yang menjadi penyebabnya kejahatan perkosaan disebabkan oleh faktor internal maupun faktor eksternal. Umur merupakan salah 
satu dari faktor internal yang mempengaruhi timbulnya kejahatan perkosaan. Umur manusia akan selalu bertambah, dan faktor umur ini akan mempengaruhi tingkah laku manusia dilihat dari segi fisik, psikis dan sosiologis.

Sedangkan faktor eksternal, meliputi faktor bacaan atau faktor film yang mengandung unsur pornografi serta faktor keluarga. Dan juga faktor lainnya adalah faktor kesempatan karena adanya kesempatan itulah perkosaan itu bisa terjadi. Suatu kejahatan bisa terjadi karena adanya kesempatan yang membuat pelaku melakukan kejahatan tersebut.

Upaya atau cara melakukan kejahatan kebanyakan dilatar belakangi oleh faktor kesempatan. Faktor kesempatan merupakan salah satu faktor eksternal pula yang mempengaruhi timbulnya kejahatan perkosaan. Seperti dijelaskan diatas, bahwa bacaan dan film yang mengandung unsur pornografi akan mempengaruhi seseorang untuk melakukan kejahatan pemerkosaan. Pesan inti dari pornografi adalah semua perempuan pada dasarnya adalah pelacur, yang berarti pula digunakan untuk kepentingan seksual.

Memang mengenai pornografi terdapat 2 pandangan umum masyarakat yang bertolak belakang. Di satu pihak mengatakan bahwa pornografi adalah amoral karena memotret seksualitas secara vulgar untuk merangsang birahi. Di pihak lain, mengatakan bahwa pornografi hanyalah ekspresi kebebasan, ekspresi dari seksualitas yang tidak merugikan masyarakat bahkan membantu masyarakat untuk lepas dari represi seksual.

Selanjutnya berkembang dengan adanya pandangan yang melihat pornografi sebagai kegiatan atau produk yang merendahkan peran dan status perempuan menjadi sekedar objek seksual yang boleh dieksploitasi dan dimanipulasi. Dampak negatif dari penyebaran pornografi ini selain dapat merangsang birahi laki-laki dewasa dan meningkatkan fantasi gairah dalam hubungan seks, juga akan memberikan efek buruk khususnya bagi anak-anak yang belum mengerti apapun mengenai seks. Seorang anak akan mulai terpengaruh pikirannya dengan tontonan tersebut dan timbul keinginan untuk mencoba dengan lawan jenisnya tanpa ada perasaan bersalah pada dirinya.

Pendampingan dan perhatian orang tua ini sangat penting. Keluarga merupakan unit yang terkecil dari masyarakat yang terdiri dari ayah, ibu dan anak. 
Anak yang baru dilahirkan pastilah dibesarkan dan memperoleh pendidikan serta mengadakan sosialisasi pertama kali dalam keluarga. Bersosialisasi dengan masyarakat sekitar tempat tinggal. Perkosaan merupakan kejahatan seksualitas yang bisa disebabkan oleh berbagai faktor. Kejahatan ini cukup kompleks penyebabnya dan tidak berdiri sendiri.

Penyebabnya dapat dipengaruhi oleh kondisi yang mendukung, keberadaan korban yang secara tidak langsung mendorong pelakunya dan bisa jadi karena ada unsur-unsur lain yang mempengaruhinya, terkait dengan posisi korban dalam hubungannya dengan pelakunya. Artinya sudah ada relasi lebih dulu (dalam ukuran internet tertentu) antara korban dengan pelakunya. Dalam setiap kasus perkosaan paling tidak melibatkan tiga hal, yakni: pelaku, korban dan situasi serta kondisi. Ketiga hal tersebut tidak dapat dipisahkan satu sama lain. Masing-masing mempunyai andil sendiri-sendiri dalam mendorong timbulnya suatu tindak pidana perkosaan.

Pendapat itu menunjukkan bahwa perkosaan dapat terjadi bukan sematamata disebabkan oleh dorongan seksual yang tidak bisa dikendalikan dan membutuhkan pelampiasan, namun juga dapat disebabkan oleh faktor emosi seperti hasrat pelaku untuk melakukan balas dendam terhadap diri perempuan yang sebelumnya pernah menyakitinya, atau menjadikan setiap perempuan sebagai sasaran kemarahannya, sehingga harus dijadikan korbannya.

Selain itu, terjadinya perkosaan juga didukung oleh peran pelaku, posisi korban dan pengaruh lingkungan. Pelaku menjadi gambaran sosok manusia yang gagal mengendalikan emosi dan naluri seksualnya secara wajar, sementara korban (dalam kasus-kasus tertentu) juga memerankan dirinya sebagia faktor kriminogen, artinya sebagai pendorong langsung maupun tidak langsung terhadap terjadinya perkosaan. Posisi pelaku dengan korban ini pun didukung oleh peran lingkungan (seperti jauh dari keramaian, sepi dan ruang tertutup) yang memungkinkan pelaku dapat leluasa menjalankan aksi-aksi jahatnya.

Perempuan yang bepergian sendiri di malam hari (situasi), tanpa didampingi suami, orang tua atau unsur keluarga dekatnya, sementara bepergian terkait dengan kepentingan yang menyita waktu dan banyak berhubungan dengan lawan jenisnya merupakan sosok perempuan yang berada dalam ancaman bahaya. 
Dimensi atau waktu produktif yang digarap perempuan tanpa pendamping akhirnya diposisikan sebagai "saat rentan" atau kondisi yang rawan terjadinya kriminalitas bagi perempuan. Perempuan menjadi subjek sosial yang dikorbankan lawan jenisnya. Kasus perkosaan misalnya jelas-jelas menempatkan perempuan sebatas sebagai subordinasi dan objek kepentingan (kebutuhan, kepuasan dan keserakahan seksual) laki-laki.

Kalau perempuan itu menjadi perempuan karier, maka karier yang dilakukannya juga mudah dihadapkan dengan berbagai macam tantangan yang dapat membahayakan harkatnya, seperti pelecehan dan kekerasan seksual. Banyaknya perempuan yang terlibat dengan kegiatan-kegiatan produktif di luar rumah adalah dapat membuka kesempatan atau menstimulasi iklim kriminogen terhadap terjadinya tindak kejahatan seksual, bilamana aktivitasnya itu lepas dari perlindungan yang menjamin keselamatannya.

Artinya, ketika perempuan makin terlibat aktif dalam kegiatan-kegiatan produktif yang serba bebas, sementara disisi lain kegiatan-kegiatan itu lepas dari kontrol moral agamanya, maka cukup terbuka peluang atau kemungkinan keselamatan perempuan itu tidak terjamin lagi.

Kedekatan hubungan antara lawan jenis (laki-laki dengan perempuan yang bukan isterinya atau bukan muhrimnya) merupakan faktor yang cukup berpengaruh terhadap terjadinya perkosaan. Pihak pelaku memang bersalah, namun kesalahan yang diperbuat itu bisa disebabkan oleh kesalahan-kesalahan yang secara tidak langsung diperbuat oleh korban. Pelaku memanfaatkan kelengahan, kelemahan dan barangkali kesalahan korban yang secara langsung maupun tidak perilakunya telah mendorong pelaku berbuat jahat. Perempuan (korban) cepat percaya dengan bujuk-rayu penampilan dan kedekatan hubungan, yang mengakibatkannya berada dalam posisi tergantung atau membutuhkan keberadaan laki-laki (pelaku).

Psikolog itu lebih menekankan faktor kriminogen perkosaan yang bersumber pada kesalahan pelaku, yang gagal mengendalikan nafsu seksualnya. Hasrat seksualnya yang cukup besar tidak diikuti dengan upaya pelampiasan yang dibenarkan secara hukum dan agama. Ada potensi dalam diri pelakunya itu potensi distabilitas psikologis atau ketidakseimbangan kejiwaan, sehingga 
mencari korban kompensasi, dan diagnosisnya melalui korban yang diperkosanya. Dalam hal ini perilaku-perilaku si korban, disadari atau tidak, merangsang timbulnya perkosaan. Sebagai contoh, seorang wanita berjalan sendiri di tempat yang sepi, cara korban berpakaian yang dapat merangsang seseorang untuk melakukan kejahatan perkosaan.

Mengenai posisi korban yang secara tidak langsung turut ambil bagian terhadap terjadinya perkosaan. Artinya, ada sikap, perilaku, cara menempatkan diri, cara bergaul dan hadir pada suasana yang menurut pandangan umum tidak lazim, yang dapat mendorong emosi dan nafsu laki-laki untuk berbuat tidak senonoh dan memperkosanya. Korban telah menempatkan dirinya sebagai "pelaku secara tidak langsung, karena apa yang diperbuatnya telah mendorong terjadinya kriminalitas".

Meningkatnya kasus perkosaan terkait erat dengan aspek sosial-budaya. Budaya yang semakin terbuka, pergaulan yang semakin bebas, cara berpakaian kaum hawa yang semakin merangsang, dan kadang-kadang dengan berbagai perhiasan mahal, kebiasaan bepergian jauh sendirian, adalah faktor-faktor dominan yang mempengaruhi tingginya frekuensi kasus perkosaan. Belum lagi mutu penghayatan keagamaan masyarakat yang semakin longgar. Belum lagi vonis hakim terhadap pelaku perkosan yang tak setimpal. Dapat disimpulkan bahwa faktor penyebab perkosaan setidak-tidaknya adalah sebagai berikut :

1. Pengaruh perkembangan budaya yang semakin tidak menghargai etika berpakaian yang menutup aurat, yang dapat merangsang pihak lain untuk berbuat tidak senonoh dan jahat.

2. Gaya hidup atau mode pergaulan di antara laki-laki dan perempuan yang semakin bebas, tidak atau kurang bisa lagi membedakan antara yang seharusnya boleh dikerjakan dengan yang dilarang dalam hubungannya dengan kaedah akhlaknya mengenai hubungan laki-laki dengan perempuan.

3. Rendahnya pengalaman dan penghatayan terhadap norma-norma keagamaan yang terjadi di tengah masyarakat. Nilai-nilai keagamaan yang semakin terkikis di masyarakat, atau pola relasi horizontal yang 
cenderung makin meniadakan peran agama adalah sangat potensial untuk mendorong seseorang berbuat jahat dan merugikan orang lain.

4. Tingkat kontrol masyarakat (social control) yang rendah, artinya berbagai perilaku yang diduga sebagai penyimpangan, melanggar hukum dan norma keagamana kurang mendapatkan responsi dan pengawasan dari unsur-unsur masyarakat.

5. Putusan hakim yang terasa tidak adil, seperti putusan yang cukup ringan yang dijatuhkan pada pelaku. Hal ini dimungkinkan dapat mendorong anggota-anggota masyarakat lainnya untuk berbuat keji dan jahat. Artinya mereka yang hendak berbuat jahat tidak merasa takut lagi dengan sanksi hukum yang akan diterimanya.

6. Ketidakmampuan pelaku untuk mengendalikan emosi dan nafsu seksualnya. Nafsu seksualnya dibiarkan mengembara dan menuntutnya untuk dicarikan kompensasi pemuasnya.

7. Keinginan pelaku untuk melakukan (melampiaskan) balas dendam terhadap sikap, ucapan (keputusan) dan perilaku korban yang dianggap menyakiti dan merugikannya.

\section{PERLINDUNGAN HUKUM TERHADAP ANAK PELAKU PEMERKOSAAN}

Perlindungan hukum disini diberikan kepada anak yang menjadi pelaku dari kejahatan seperti perkosaan, pencabulan dan pelecehan seksual. Sebagaimana kita ketahui besama bahwa kepedulian umat manusia atas eksistensi anak dari masa depannya telah mendapatkan legitimasi dengan diratifikasinya Konvensi Perjuangan Besar Bangsa Indonesia tentang hak-hak anak.

Kita menyadari sepenunya bahwa penderitaan seseorang yang menjadi korban kejahatan ini tidak berhenti pada saat selesainya kejahatan tersebut dilakukannya. Bukan saja ia harus berusaha sendiri untuk menyembuhkan luka yang dideritanya baik fisik maupun psikis dengan biaya sendiri pula, ditambah lagi ia harus menyediakan waktu, dana dan upaya turut berperan serta dalam proses pengadilan pidana terhadap kasus yang menimpa dirinya.

Anak sebagai pelaku kejahatan kesusilaan ini memerlukan dan mempunyai 
hak dengan dasar hukum (legal rigths) untuk mendapatkan uluran solidaritas sebagai bentuk hak asasi manusia. Jadi hal ini untuk mengusahakan perlindungan hukum sebagai dasar untuk dapat menindaklanjuti penyembuhan fisik, kejiwaan dan memulihkan kembali hak anak yang seharusnya dimilikinya.

\section{Perlindungan Hukum Anak}

Jika kita berbicara mengenai anak, maka hal ini tidak akan lari dari pembahasan mengenai perlindungan anak sebagai pelaku. Jadi yang harus mengusahakan perlindungan anak adalah setiap anggota masyarakat sesuai dengan kemampuannya dengan berbagai macam usaha dalam situasi dan kondisi tertentu. Perlindungan anak adalah suatu usaha yang mengadakan kondisi dimana anak dapat melaksanakan hak dan kewajibannya. Anak yang menjadi pelaku kekerasan sesungguhnya juga memiliki hak asasi manusia, jadi tidak hanya pelaku tindak pidana sebagaimana sejumlah ketentuan hukum yang lebih cenderung melindungi terdakwa atau pelaku.

Dalam hal pengertian perkosaan, pendapat para ahli dalam mendefinisikan tentang perkosaan berbeda-beda seperti yang dikemukakan oleh Soetandyo Wingjosoebroto: perkosaan adalah suatu usaha melampiaskan nafsu seksual oleh seorang laki-laki terhadap seorang perempuan dengan cara menurut moral dan atau hukum yang berlaku melanggar. (A Wahid \& M. Irfan, 2001, 25)

Menurut Wirjono perkosaan sebagai terjemahan dari kualifikasi aslinya (Belanda) yakni Verkrachting tidaklah tepat karena istilah perkosaan tidak menggambarkan secara tepat tentang perkosaan menurut arti yang sempit sebenarnya, dari kualifikasi Verkrachting, yakni perkosaan untuk bersetubuh oleh karena itu menurut beliau kualifikasi yang tepat adalah perkosaan untuk bersetubuh. (Adam Chazawi, 2005, 62)

Apabila rumusan perkosaan diatas dirinci dari unsur-unsur sebagai berikut:

a. Perbuatan : memaksa;

b. Caranya : dengan kekerasan; ancaman kekerasan

c. Objek : seorang perempuan bukan istrinya

d. Bersetubuh dengan dia

Asumsi yang tak sependapat dalam hal mendefinisikan perkosaan tidak memperhitungkan perlu atau tidaknya unsur mengenai keluarnya air mani seperti 
yang dikemukakan oleh PAF Lamintang dan Djisman Samosir yang berpendapat: "perkosaan adalah perbuatan seseorang yang dengan kekerasan atau ancaman kekerasan memaksa seorang wanita untuk melakukan persetubuhan di luar ikatan perkawinan dengan dirinya.

\section{Perlindungan Hukum Terhadap Anak Pelaku Pemerkosaan}

Dalam upaya memberikan perlindungan terhadap kepentingan dan hakhak anak yang berhadapan dengan hukum, pemerintah Indonesia telah mengeluarkan beberapa peraturan perundang-undangan terkait dengan anak di mata hukum. Anak adalah produk hukum pemerintah yang harus dilindungi secara hukum. Masalah perlindungan hak-hak anak yang berhadapan dengan hukum terdapat dalam pasal 66 Undang-Undang Nomor 39 tahun 1999, menentukan bahwa:

a. Setiap anak berhak untuk tidak dijadikan sasaran penganiayaan, penyiksaan atau penjatuhan hukuman yang tidak manusiawi,

b. Hukuman mati atau hukuman seumur hidup tidak dapat dijatuhkan untuk pelaku tindak pidana yang masih anak;

c. Setiap anak berhak untuk tidak dirampas kebebasannya secara melawan hukum;

d. Penangkapan, penahanan atau pidana penjara anak hanya boleh dilakukan sesuai dengan hukum yang berlaku dan hanya dapat dilaksanakan sebagai upaya terakhir;

e. Setiap anak yang dirampas kebebasannya berhak mendapatkan perlakuan manusiawi dan dengan memperhatikan kebutuhan, pengembangan pribadi sesuai dengan usianya dan harus dipisahkan dari orang dewasa, kecuali demi kepentingannya;

f. Setiap anak yang dirampas kebebasannya berhak memperoleh bantuan hukum atau bantuan lainnya secara efektif dalam setiap tahapan upaya hukum yang berlaku;

g. Setiap anak yang dirampas kebebasannya berhak untuk membela diri dan memperoleh keadilan di depan Pengadilan Anak yang objektif dan tidak memihak dalam sidang yang tertutup untuk umum.

Selanjutnya dalam Undang-Undang Nomor 11 tahun 2012 tentang Sistem 
Peradilan Pidana Anak terdapat substansi yang paling mendasar dalam UndangUndang ini, adalah pengaturan secara tegas mengenai Keadilan Restoratif dan Diversi yang dimaksudkan untuk menghindari dan menjauhkan anak dari proses peradilan, sehingga dapat menghindari stigmatisasi terhadap Anak yang berhadapan dengan hukum dan diharapkan Anak dapat kembali ke dalam lingkungan sosial secara wajar.

Oleh karena itu, sangat diperlukan peran serta semua pihak dalam rangka mewujudkan hal tersebut. Proses itu harus bertujuan pada terciptanya Keadilan Restoratif, baik bagi Anak maupun bagi korban. Keadilan Restoratif merupakan suatu proses Diversi, yaitu semua pihak yang terlibat dalam suatu tindak pidana tertentu bersama-sama mengatasi masalah serta menciptakan suatu kewajiban untuk membuat segala sesuatunya menjadi lebih baik dengan melibatkan korban, anak, dan masyarakat dalam mencari solusi untuk memperbaiki, rekonsiliasi, dan menenteramkan hati yang tidak berdasarkan pembalasan.

Selanjutnya berdasarkan ketentuan yang terdapat dalam Undang-Undang Nomor 11 tahun 2012 tentang Sistem Peradilan Pidana Anak, ada beberapa pasal berhubungan dengan masalah perlindungan anak yang berhadapan dengan hukum, yaitu Pasal 1 angka 2 yang menyatakan bahwa :

a. Pasal 1angka 1 berbunyi Sistem Peradilan Pidana Anak adalah keseluruhan proses penyelesaian perkara Anak yang berhadapan dengan hukum, mulai tahap penyelidikan sampai dengan tahap pembimbingan setelah menjalani pidana.

b. Pasal 1 angka 2 berbunyi Anak yang Berhadapan dengan Hukum adalah anak yang berkonflik dengan hukum, anak yang menjadi korban tindak pidana, dan anak yang menjadi saksi tindak pidana.

c. Pasal 1 angka 3 berbunyi Anak yang Berkonflik dengan Hukum yang selanjutnya disebut Anak adalah anak yang telah berumur 12 (dua belas) tahun, tetapi belum berumur 18 (delapan belas) tahun yang diduga melakukan tindak pidana.

d. Pasal 1 angka 6 berbunyi Keadilan Restoratif adalah penyelesaian perkara tindak pidana dengan melibatkan pelaku, korban, keluarga pelaku/korban, dan pihak lain yang terkait untuk bersama-sama mencari 
penyelesaian yang adil dengan menekankan pemulihan kembali pada keadaan semula, dan bukan pembalasan.

e. Pasal 1 angka 7 berbunyi Diversi adalah pengalihan penyelesaian perkara Anak dari proses peradilan pidana ke proses di luar peradilan pidana.

Kemudian dalam pasal selanjutnya lebih dipertegas dan diperjelas yaitu tepatnya dalam pasal 2 dilaksanakan berdasarkan asas:
a. pelindungan;
b. keadilan;
c. non-diskriminasi;
d. kepentingan terbaik bagi Anak;
e. penghargaan terhadap pendapat Anak;
f. kelangsungan hidup dan tumbuh kembang Anak;
g. pembinaan dan pembimbingan Anak;
h. proporsional;
i. perampasan kemerdekaan dan pemidanaan sebagai upaya terakhir; dan
j. penghindaran pembalasan.

Dalam pasal berikutnya berkenaan dengan anak yang berhadapan dengan hukum maka seorang anak harus tetap diperhatikan dan di prioritaskan dari sisi fisik, psikologis dan pandedodisnya supaya perkembangan tidak terhambat oleh karena sedang berkonflik dengan hukum. Dimana setiap Anak yang sedang dalam proses peradilan pidana berhak untuk sebagaimana yang dinyatakan dalam pasal 3:

a. diperlakukan secara manusiawi dengan memperhatikan kebutuhan sesuai dengan umurnya;

b. dipisahkan dari orang dewasa;

c. memperoleh bantuan hukum dan bantuan lain secara efektif;

d. melakukan kegiatan rekreasional;

e. bebas dari penyiksaan, penghukuman atau perlakuan lain yang kejam, tidak manusiawi, serta merendahkan derajat dan martabatnya;

f. tidak dijatuhi pidana mati atau pidana seumur hidup;

g. tidak ditangkap, ditahan, atau dipenjara, kecuali sebagai upaya terakhir 
dan dalam waktu yang paling singkat;

h. memperoleh keadilan di muka pengadilan Anak yang objektif, tidak memihak, dan dalam sidang yang tertutup untuk umum;

i. tidak dipublikasikan identitasnya;

j. memperoleh pendampingan orang tua/wali dan orang yang dipercaya oleh Anak;

k. memperoleh advokasi sosial;

1. memperoleh kehidupan pribadi;

m. memperoleh aksesibilitas, terutama bagi anak cacat;

n. memperoleh pendidikan;

o. memperoleh pelayananan kesehatan; dan

p. memperoleh hak lain sesuai dengan ketentuan.

Pada pasal (5) di dalam sistem peradilan pidana anak wajib mengedepankan keadilan restoratif yang bermuara tetap menjaga supaya anak jangan sampai menghambat perkembangannya sebagaimana disebutkan di bawah ini, yaitu:

(1) Sistem Peradilan Pidana Anak wajib mengutamakan pendekatan Keadilan Restoratif.

(2) Sistem Peradilan Pidana Anak sebagaimana dimaksud pada ayat (1) meliputi:

a. penyidikan dan penuntutan pidana Anak yang dilaksanakan sesuai dengan ketentuan peraturan perundang-undangan, kecuali ditentukan lain dalam undang-undang ini;

b. persidangan Anak yang dilakukan oleh pengadilan di lingkungan peradilan umum; dan

c. pembinaan, pembimbingan, pengawasan, dan/atau pendampingan selama proses pelaksanaan pidana atau tindakan dan setelah menjalani pidana atau tindakan.

(3) Dalam Sistem Peradilan Pidana Anak sebagaimana dimaksud pada ayat (2) huruf a dan huruf b wajib diupayakan Diversi.

Berkenaan dengan diversi di dalam Undang-Undang Nomor 11 tahun 2012 tentang Sistem Peradilan Pidana Anak di tempatkan secara eklusif dengan 
kekhususan dalam satu pasal, yaitu tepatnya berada pada pasal 6 menjelaskan diversi sebagai sebuah win-win solution dalam hal untuk menyelesaikan permasalahan anak yang sedang berkonflik dengan hukum dikarenakan melakukan suatu kejahatan, dalam hal ini yaitu anak yang melakukan perkosaan, sehingga perkembangan dan pertumbuhan sebagai anak tidak terganggu dan diharapkan kemudian hari dapat menjadi manusia seutuhnya. Diversi bertujuan:

a. mencapai perdamaian antara korban dan Anak;

b. menyelesaikan perkara Anak di luar proses peradilan;

c. menghindarkan Anak dari perampasan kemerdekaan;

d. mendorong masyarakat untuk berpartisipasi; dan

e. menanamkan rasa tanggung jawab kepada Anak.

Selanjutnya berdasarkan ketentuan yang terdapat dalam Undang-Undang Nomor 23 Tahun 2002, ada beberapa pasal berhubungan dengan masalah perlindungan anak yang berhadapan dengan hukum yaitu:

a. Pasal 1 angka (2), yang menentukan bahwa perlindungan anak adalah segala kegiatan untuk menjamin dan melindungi anak dan hak-haknya agar dapat hidup, tumbuh, berkembang dan berpartisipasi secara optimal sesuai dengan harkat dan martabat kemanusiaan, serta mendapat perlindungan dari kekerasan dan diskriminasi.

b. Pasal 1 angka (15), menentukan bahwa perlindungan khusus adalah perlindungan yang diberikan kepada anak dalam situasi darurat, anak yang berhadapan dengan hukum, anak dari kelompok minoritas dan terisolasi, anak yang dieksploitasi secara ekonomi dan/atau seksual, anak yang diperdagangkan, anak yang menjadi korban penyalahgunaan narkotika, alkohol, psikotropika dan zat adiktif lainnya (napza), anak korban penculikan, penjualan, perdagangan, anak korban kekerasan baik fisik dan/atau mental, anak yang menyandang cacat dan anak korban perlakuan salah dan penelantaran.

c. Pasal 2, menentukan bahwa penyelenggaraan perlindungan anak berasaskan Pancasila dan berlandaskan UUD 1945 serta prinsip-prinsip dasar Konvensi Hak-hak Anak meliputi:

1. non diskriminasi; 
2. kepentingan yang terbaik bagi anak;

3. hak untuk hidup, kelangsungan hidup dan perkembangan;

4. penghargaan terhadap pendapat anak.

d. Pasal 3, menentukan bahwa perlindungan anak bertujuan untuk menjamin terpenuhinya hak-hak anak agar dapat hidup, tumbuh, berkembang dan berpartisipasi secara optimal sesuai dengan harkat dan martabat kemanusiaan, serta mendapat perlindungan dari kekerasan dan diskriminasi, demi terwujudnya anak Indonesia berkualitas, berakhlak mulia dan sejahtera.

e. Pasal 16, menentukan bahwa:

1) Setiap anak berhak memperoleh perlindungan dari sasaran penganiayaan, penyiksaan atau penjatuhan hukuman yang tidak manusiawi.

2) Setiap anak berhak untuk memperoleh kebebasan sesuai dengan hukum.

3) Penangkapan, penahanan atau tindak pidana penjara anak hanya dilakukan apabila sesuai dengan hukum yang berlaku dan hanya dapat dilakukan sebagai upaya terakhir.

f. Pasal 17, menentukan bahwa:

Angkat (4), Setiapanak yang dirampas kebebasannya berhak untuk:

1) mendapatkan perlakuan secara manusiawi dan penempatannya dipisahkan dari orang dewasa;

2) memperoleh bantuan hukum atau bantuan lainnya secara efektif dalam setiap tahapan upaya hukum yang berlaku;

3) membela diri dan memperoleh keadilan di depan pengadilan anak yang objektif dan tidak memihak dalam siding tertutup untuk umum; Angka (5), Setiap anak yang menjadi korban atau pelaku kekerasan seksual atau yang berhadapan dengan hukum berhak dirahasiakan.

g. Pasal 18, menentukan bahwa setiap anak yang menjadi korban atau pelaku tindak pidana berhak mendapatkan bantuan hukum dan bantuan lainnya.

h. Pasal 59, menentukan bahwa pemerintah dan lembaga negara lainnya 
berkewajiban dan bertanggung jawab untuk memberikan perlindungan khusus kepada anak dalam situasi darurat, anak yang berhadapan dengan hukum, anak dari kelompok minoritas dan terisolasi, anak tereksploitasi secara ekonomi dan/atau seksual, anak yang diperdagangkan, anak yang menjadi korban penyalahgunaan narkotika, alkohol, psikotropika, dan zat adiktif lainnya (napza), anak korban penculikan, penjualan dan perdagangan, anak korban kekerasan baik fisik dan/atau mental, anak yang menyandang cacat dan anak korban perlakuan salah dan penelantaran.

i. Pasal 64, menentukan bahwa:

Angka (6) Perlindungan khusus bagi anak yang berhadapan dengan hukum sebagaimana dimaksud dalam Pasal 59 meliputi anak yang berhadapan dengan hukum dan anak korban tindak pidana, merupakan kewajiban dan tanggungjawab pemerintah dan masyarakat.

Angka (7) Perlindungan khusus bagi anak yang berhadapan dengan hukum dilaksanakan melalui:

a. perlakuan atas anak secara manusiawi sesuai dengan martabat dan hak-hak anak.

b. penyediaan petugas pendamping khusus anak sejak dini.

c. penyediaan sarana dan prasarana khusus.

d. penjatuhan sanksi yang tepat untuk kepentingan terbaik bagi anak.

e. pemantauan dan pencatatan terus menerus terhadap perkembangan anak yang berhadapan dengan hukum.

f. pemberian jaminan untuk mempertahankan hubungan dengan orang tua atau keluarga.

g. perlindungan dari pemberitaan identitas melalui media massa dan untuk menghindari labelisasi.

Sistem Pengadilan Pidana Anak (Juvenile Justice System) adalah segala unsur sistem pengadilan pidana yang terkait di dalam penanganan kasus-kasus kenakalan anak:

1. Pertama, polisi sebagai institusi formal ketika anak nakal pertama kali 
bersentuhan dengan sistem Pengadilan, yang juga akan menentukan apakah anak akan dibebaskan atau diproses lebih lanjut.

2. Kedua, jaksa dan lembaga pembebasan bersyarat yang juga menentukan apakah anak dibebaskan atau diproses ke pengadilan anak.

3. Ketiga, Pengadilan Anak, tahapan ketika anak ditempatkan dalam pilihan-pilihan, mulai dari dibebaskan sampai dimasukkan dalam institusi penghukuman.

4. Terakhir, institusi penghukuman.

Ada 2 (dua) kategori perilaku anak yang membuat berhadapan dengan hukum, yaitu:

a. Status Offender adalah perilaku kenakalan anak yang apabila dilakukan oleh orang dewasa tidak dianggap sebagai kejahatan, seperti tidak menurut, membolos sekolah atau kabur dari rumah;

b. Juvenile Delinquency adalah perilaku kenakalan anak yang apabila dilakukan oleh orang dewasa dianggap kejahatan atau pelanggaran hukum.

Pelaksanaan Sistem Pengadilan Pidana Anak ditegakkannya demi mencapai kesejahteraan anak dengan berdasar prinsip kepentingan terbaik bagi anak. Dengan kata lain, Sitem Pengadilan Pidana Anak berdasarkan pada perlindungan anak dan pemenuhan hak-hak anak (protection child and full fil ment child rights based approuch). Selanjutnya akan dibahas sistem Pengadilan anak di Kepolisian, kejaksaan dan Pengadilan. (Steven Allen, 2003, 2)

Bukan cuma itu, dengan kecendrungan membawa anak ke mesin peradilan pidana anak, maka anak-anak akan selalu menjadi target kriminalisasi. Padahal penahanan, pemidanaan, merupakan upaya terakhir (ultimum remidium). Sehingga tidak sepatutnya dibawa ke pengadilan apabila tidak perlu. Di samping itu, tidak luput juga banyak kasus yang dilaporkan ke Polisi namun tidak diproses menuju sidang anak, atau menjadi perkara yang hilang (dark number). (Paulus Hadisuprapto, 2006, 23)

Dengan demikian secara normatif, adanya kriminalisasi terhadap anak yang karenanya melanggar hak anak atas tumbuh dan kembang, dan hak anak atas perlindungan dari kekerasan dan diskriminasi karena adanya kriminalisasi anak 
dan pemenjaraan anak melanggar hak konstitusional anak dalam Pasal 28B ayat (2) UUD 1945. Secara normatif adanya kriminalisasi anak merupakan perbuatan melanggar hak konstitusional atas perlindungan dan kepastian hukum yang adil serta perlakuan sama di hadapan hukum.

Padahal berdasarkan Pasal 28D ayat (1) UUD 1945 yang menegaskan bahwa; Setiap orang berhak atas pengakuan, jaminan, perlindungan dan kepastian hukum yang adil serta perlakuan yang sama di hadapan hukum”. Atas dasar itu, maka para hakim didorong untuk menggali rasa keadilan substantif (substantive justice) di masyarakat daripada terbelenggu ketentuan undang-undang (procedural justice). (M. Mahfud MD, 2008, 6)

Sistem peradilan pidana anak, masih merupakan turunan dari sistem peradilan untuk orang dewasa. Perbedaan usia dapat bertanggung jawab secara hukum ini berkaitan dengan sistem peradilan anak yang diterapkan di negaranegara tersebut. Scotlandia tidak memiliki pengadilan khusus bagi anak delinkuen, karena anak-anak yang melakukan delinquency dibawa ke lembaga yang dikenal dengan Children's Hearing System yang tidak memiliki wewenang menjatuhkan sanksi untuk menghukum anak. (Purnianti dkk, 2004, 204)

Oleh karena itu, Sidang Anak hanyalah bermaksud membedakan Sidang Anak dengan sidang orang dewasa dengan berbagai kekhususan, misalnya, kekhususan dalam petugas penegak hukumnya, adanya alternatif pidana dan tindakan, masa tahanan yang lebih rendah, hukuman pidana yang dijatuhkan diturunkan menjadi maksimum hanya 1/2 (seperdua) saja dari ancaman pelaku dewasa, hukum acara pidana sama dengan KUHAP dengan berbagai pengecualian. Dengan demikian, hukum acara dalam sidang anak hanya turunan dari hukum acara dan sistem peradilan bagi orang dewasa. Implikasinya, secara institusional perkembangan dan kemajuan Sidang Anak tidak berjalan efektif dan cenderung terabaikan.

\section{Upaya-Upaya Penanggulangan Kejahatan Perkosaan.}

Untuk menaggulangi kejahatan perkosaan Instansi Polisi selaku yang diberikan kewenangan dapat melakukan upaya preventif. Yang dimaksud dengan upaya preventif, yaitu upaya-upaya yang dilakukan untuk mencegah terjadinya kejahatan perkosaan. Berdasarkan hasil wawancara dengan $\mathrm{Bu}$ Marti, upaya 
preventif ini dilakukan oleh Bagbinamitra (Bagian Pembinaan Kemitraan).

Upaya ini dapat meliputi kegiatan berupa pemberian penyuluhan atau himbauan kepada masyarakat untuk saling menghargai dan melindungi hak dan harga diri khususnya perempuan sebagai sesama ciptaan Tuhan. Dengan demikian pelaku tidak hanya memuaskan hawa nafsunya sendiri tetapi juga memikirkan dampak negatif yang akan terjadi kemudian, yaitu masa depan korban perkosaan yang secara rohani dan materiil sangat dirugikan.

Memberikan penyuluhan atau penerangan di desa-desa dan tempat lain tentang dampak terjadinya kejahatan perkosaan. Upaya preventif ini dilakukan oleh Bagian Binamitra, melakukan sosialisasi sekaligus penyuluhan terhadap perempuan sehingga ia dapat menjaga dirinya sendiri dari ancaman kejahatan perkosaan, di antaranya menganjurkan agar perempuan hendaknya berpakaian yang sopan. Menggunakan pakaian dengan mempertontonkan bagian tubuh yang mulus secara tidak langsung akan merangsang nafsu seks laki-laki yang melihatnya dan timbul kejahatan dalam pikirannya.

Hal ini yang biasanya disebut victim pertisipation artinya korban sendiri yang turut menimbulkan terjadinya kejahatan tersebut. Di samping itu perempuan diusahakan untuk tidak keluar malam, apalagi kalau keluar malam sendirian di tempat rawan. Jika memang terpaksa, maka diharapkan dapat mengajak teman yang bisa dipercaya. Faktor penyebab terjadinya kejahatan perkosaan sebagian besar dikarenakan adanya faktor kesempatan, yaitu tempat yang sepi (tidak ada orang lain) dan korban dalam keadaan sendirian.

Selain itu diharapkan perempuan tidak mudah terpengaruh oleh rayuan setiap orang, baik yang dikenal ataupun tidak dikenalnya. Seringkali perempuan tergoda atau terpedaya dengan sifat manis laki-laki yang tampak dari luarnya, misalnya perbuatannya yang baik, sopan dan suka menolong. Hal ini selalu melekat dan dilakukan oleh laki-laki terhadap setiap korbannya yang baru dikenalnya. Baru setelah laki-laki tersebut merasa perempuannya atau korbannya telah masuk dalam perangkapnya, ia akan melakukan aksi jahatnya yaitu memperkosa perempuan itu atau korbannya. Seharusnya agar perempuan tidak terpengaruh atau terpikat oleh rayuan setiap orang, meskipun orang tersebut telah dikenal maupun yang tidak dikenal untuk berbuat tidak sopan (melakukan 
hubungan seks) dengan menjanjikan sesuatu yang indah setelah perempuan menuruti kehendak laki-laki tersebut.

\section{PERLINDUNGAN HUKUM BAGI ANAK PELAKU PERKOSAAN DALAM ISLAM}

Dalam hukum Islam mempunyai aturan yang jelas, kedudukan anak dalam hukum islam merupakan amanah yang harus dijaga oleh kedua orang tuanya. Kewajiban mereka pula untuk mendidiknya hingga berperilaku sebagaimana yang dituntun dalam agama. Jika terjadi penyimpangan dalam tingkah laku anak, Islam dalam keadaan tertentu masih memberi kelonggaran seperti diisyaratkan sebuah hadis yang menyatakan ketidakberdosaan "ra'ful alam" seorang anak hingga mencapai akil baligh, ditandai dengan timbulnya mimpi basah (ihtilam) pada lakilaki dan haid pada perempuan. (Luthfi Assyaukani, 1998, 164)

Bila seorang anak mencuri, atau membunuh sekalipun, ia tidak bisa dikenakan hukuman apapun, bahkan, Wahbah Zuhaili dalam bukunya al-Fiqh al Islami mencatat status perbuatan anak tersebut dalam kategori fiqh belum termasuk dalam tindakan kriminak (jinayah) dalam hukum pidana Islam.

Pertanggungjawaban pidana dapat terhapus karena adanya sebab-sebab tertentu baik yang berkaitan dengan perbuatan si pelaku tindak pidana maupun sebab-sebab yang berkaitan dengan keadaan pembuat delik, seperti kejahatan yang dilakukan dalam keadaan dipaksa, tidak akan ada tuntutan hukum atas hal tersebut asalkan terbukti benarnya, kemudian kejahatan yang dilakukan oleh seseorang dalam keadaan tidak sadar seperti mengigau, meskipun dia tampak awas namun dia tetap tertidur. Maka, secara hukum dia tidak bertanggung jawab, begitu juga dengan tindak pidana yang dilakukan oleh seseorang yang masih anak-anak dan seseorang yang dalam keadaan gila atau sakit saraf. (Rahmat Hakim, 2000, 177)

Tingkatan pertama kesepakatan ulama-ulama mengatakan bahwa tidak adanya kemampuan menggunakan akal pikirannya bermula dari anak itu dilahirkan dan berakhir sampai berusia tujuh tahun. Tingkatan kedua menunjukan adanya kemampuan untuk mempergunakan akal pikirannya tetapi masih lemah. Tingkatan ini bermula dari anak berumur tujuh tahun sampai baligh. Adapun 
tingkatan ketiga menunjukan bahwa kemampuan untuk mempergunakan akal pikirannya secara sempurna dimulai dari balighnya seorang anak yang berumur 15 tahun (pendapat keumuman ulama fiqh) atau setelah berumur 18 tahun (pendapat Abu Hanifah dan Masyhur Malikiyah).

Suatu perbuatan jarimah (tindak pidana, peristiwa pidana atau delik) apabila perbuatan tersebut mengakibatkan kerugian bagi orang lain atau masyarakat baik jasad (anggota badan atau jiwa), harta benda, keamanan, tata aturan masyarakat, nama baik, perasan ataupun hal-hal yang harus dipelihara dan dijunjung tinggi keberadaanya. Selain perbuatan tersebut mengakibatkan kerugian kepada pihak lain, perbuatan tersebut juga telah ditetapkan oleh Negara dalam bentuk Undang-Undang, demikian pula dalam hukum pidana Islam, suatu perbuatan dapat dikategorikan sebagai tindak pidana (jarimah) apabila perbuatan tersebut diatur oleh nash.

Mengenai hukuman bagi anak yang melakukan tindak pidana, hukuman pidana Islam tidak memberikan ketentuan yang jelas, karena menurut Islam anak merupakan amanat yang diberikan oleh Allah SWT yang harus dijaga, dirawat sebaik mungkin. Sehingga ketika anak melakukan perbuatan melanggar hukum maka anak tersebut tidak dikenakan hukuman, dan sebagai gantinya yang menjalankan hukuman adalah orang tuanya.

Menurut syariat Islam, pertanggungjawaban pidana anak terhadap apa yang telah dilakukannya terdiri atas 2 perkara, yaitu kekuatan berfikir dan pilihan (iradah dan ikhtiar). Oleh karena itu, kedudukan anak berbeda-beda menurut perbedaan masa yang dilalui semasa hidupnya. (A Hanafi, Asas-asas, 1999, 280)

Unsur-unsur Jarimah dalam hukum pidana Islam, yaitu :

1. Adanya nash yang melarang dan mengancam perbuatan itu

2. Adanya tingkah laku yang membentuk jarimah

3. Si pembuat adalah mukallaf

Pada dasarnya orang yang melakukan jarimah itu dihukum, tetapi ada diantaranya yang tidak dihukum karena mabuk, gila dan belum dewasa. (Amrsum, Junayat, 1989, 6) 


\section{PENUTUP}

\section{A. Kesimpulan}

Penulis menyimpulkan beberapa hal terkait dari hasil penulisan ini yang telah dibahas, yaitu:

1. Perkosaan termasuk dalam kejahatan, kekerasan, kekerasan seksual dan juga merupakan hak asasi perempuan yang diinjak-injak. Perlu diketahui misalnya dalam perpektif masyarakat pada lazimnya bahwa kejahatan seksual itu bermacam-macam, seperti perzinahan, homoseksual, samen leven (kumpul kebo), lesbian, protitusi (pelacuran), pencabulan, perkosaan promiskuitas (hubungan seksual yang dilakukan di luar ikatan perkawinan dengan cara berganti-ganti pasangan).

2. faktor-faktor yang melatar belakangi terjadinya kejahatan perkosaan, faktor yang menjadi penyebabnya kejahatan perkosaan disebabkan oleh faktor internal maupun faktor eksternal. Umur merupakan faktor internal yang mempengaruhi timbulnya kejahatan perkosaan, umur ini akan mempengaruhi tingkah laku manusia dilihat dari segi fisik, psikis dan sosiologis. Sedangkan faktor eksternal, meliputi faktor bacaan atau faktor film yang mengandung unsur pornografi, faktor keluarga, faktor kesempatan karena adanya kesempatan. Namun tentu dimensi yang paling dominan adalah terjadi krisis nilai-nilai agama dan moral, yang secara lahiriah dan batiniah merupakan batasan bagi seorang manusia untuk bertindak dan bersikap, faktor ekonomi, dll.

3. Anak sebagai pelaku kejahatan kesusilaan ini memerlukan dan mempunyai hak dengan dasar hukum (legal rigths) untuk mendapatkan uluran solidaritas sebagai bentuk hak asasi manusia. Jadi hal ini untuk mengusahakan perlindungan hukum sebagai dasar untuk dapat menindaklanjuti penyembuhan fisik, kejiwaan dan memulihkan kembali hak anak yang seharusnya dimilikinya. Dalam perundang-undang berkenaan dengan anak, adalah produk hukum pemerintah yang berkaitan tentang anak yang harus dilindungi secara hukum.

4. Dalam hukum Islam mempunyai aturan yang jelas, kedudukan anak dalam hukum Islam merupakan amanah yang harus dijaga oleh kedua orang 
tuanya. Kewajiban mereka pula untuk mendidiknya hingga berperilaku sebagaimana yang dituntun dalam agama. Jika terjadi penyimpangan dalam tingkah laku anak, Islam dalam keadaan tertentu masih memberi kelonggaran seperti diisyaratkan sebuah hadis yang menyatakan ketidakberdosaan "ra'ful alam" seorang anak hingga mencapai akil baligh, ditandai dengan timbulnya mimpi basah (ihtilam) pada laki-laki dan haid pada perempuan.

\section{B. Saran-Saran}

Berikut saran-saran yang dapat diberikan penulis berkenaan dengan penulisan ini, yaitu:

1. Kejahatan perkosaan adalah suatu kejahatan yang klasik dan faktor-faktor bisa berasal dari dorongan internal (kejiwaan) atau ekternal (luar atau lingkungan) yang menjadikan kejahatan itu dilakukan oleh seorang anak, oleh karena itu baik orang tua, masyarakat, pemerintah untuk membuat suatu tatanan kehidupan dalam masyarakat yang mengurangi faktor-faktor terjadinya kejahatan perkosaan tersebut.

2. Untuk memngoptimalkan pranata-pranata baik secara kelembagaan maupun kesadaran dalam masyarakat, mengawasi dan mengamati pergaulan ataupun kegiatan yang mengarah pada terjadinya tindak kejahatan pemerkosaan yang dilakukan oleh seorang anak yang mana secara psikologis anak dalam perkembangan jiwanya masih labil dan suka mencontoh sesuatu yang di lihat, di rasa dan di dengar, dan etika dan nilainilai agama harus ditanankan sejak dini sehingga dapat menjadi filter akibat pergaulan dan kegiatan dalam zaman era globalisasi ini yang semakin jauh dari tuntunan moral dan budaya kearifan lokal. 


\section{DAFTAR PUSTAKA}

Allen, Steven. Analisa Situasi Sistem Pengadilan Pidana Anak (Juvenile Justice System) di Indonesia. Kata Pengantar, dalam Purnianti, Mamik Sri Supatmi, dan Ni Made Martini Tinduk. UNICEF, Indonesia, 2003.

Amrsum. Jinayat (Hukum Peradilan Islam). Cetakan 2, Yogyakarta: perpusatakaan FH UII, 1989.

Asnifriyanti, "Penghapusan Diskriminasi terhadap Wanita dan Anak Perempuan”. 2008.

Assyaukani, Luthfi. Politik HAM dan Isu-Isu Tekhnologi Fikih Kontemporer. Cetakan 1, Bandung: Pustaka Hidayah, 1998.

Chazawi, Adam. Tindak Pidana Mengenai Kesopanan. Jakarta: Raja Grafindo, 2005.

Gosita, Arief. Bunga Rampai Viktimisasi. 2003.

Hadi, P. Hardodo. Jati Diri Manusia Berdasar Filsafat Organisme Whitehead. Yogyakarta: Kanisius, 1997.

Hadisuprapto, Paulus. "Peradilan Restoratif: Model Peradilan Anak Indonesia Masa Datang”. Pidato Pengukuhan Jabatan Guru Besar Fakultas Hukum Universitas Diponegoro, 2006.

Hakim, Rahmat. Hukum Pidana Islam (Fiqh Jinayah). Bandung: Pustaka Setia, 2000.

Katjasungkana, Nursyahbani. "Penghapusan Diskriminasi terhadap Perempuan", 2007.

Kunarto. "PBB dan Imlementasi Hak Asasi Manusia Dalam Penegakan Hukum", 2005.

Maftuh, Bunyamin. Sosiologi Umum II Untuk SMU. Bandung: Ganeca Exact, 1996.

Majda, El Muhtaj. Memahami Integritas Hak-hak Anak dan Impelementasinya, dalam sulaiman Zuhdi Manik (Ed.), kekerasan Terhadap Anak, dalam Wacana dan Realitas. Medan: PKPA,1999.

MD. M. Mahfud, "Penegakan Keadilan di Pengadilan”, Opini di harian Kompas, 22 Desember 2008. 
Purnianti, dkk. “Analisa Situasi Sistem Peradilan Pidana Anak (Juvenile Justice System) di Indonesia”. UNICEF, 2003.

Romli, Atmasasmita. Teori dan Kapita Selekta Kriminologi. Bandung: Refika Aditama, 2005.

Shihab, M. Quraish. Membumikan Al-Qur'an. Bandung: Mizan, 1997.

Soesilo, R. Taktik dan Tehnik Penyidikan Perkara Kriminal. Bogor: Politeia, 1980.

Wahid, M. Irfan. A. Perlindungan Terhadap Korban Kekerasan Seksual (Advokasi Atas Hak Asasi Perempuan). Malang: Refika Aditama, 2001.

Walgito, Bimo. “Psikologi Sosial”. Yogyakarta: Andi Ofset, 1997.

Indonesia Daily News Online, 4 Agustus 1998.

Sriwijaya Pos, 3 Januari 2003. 